Kateryna Drozdova,

PhD (Candidate of Pedagogical Sciences), senior lecturer, Department of Theory and Methods of Physical Education, Physical Therapy and Sports Medicine, South Ukrainian National Pedagogical University named after K. D. Ushynsky,

4, Fontanska Doroha Str., Odesa, Ukraine

\title{
FORMING AXIOLOGICAL ATTITUDE TOWARDS \\ HEALTHY LIFESTYLE AMONG JUNIOR SCHOOLCHILDREN
}

The current stage of the development of society requires the consolidation of consciousness around the idea of building a humanistic-oriented, democratic state. The issues of modernization of education on the principles of democratization and humanization, the creation of conditions for the full development of the intellectual and professional qualities of a person and the formation of a high level of health are of a great importance nowadays. The instilling of the responsible attitude in an individual towards both his/her own health and the health of other people is considered to be one of the priorities of the educational system in Ukraine. The formation of health culture, skills of healthy lifestyle, axiological attitude towards one's own health must be started in the pre-school age. In Ukraine a great number of children have health problems and poor physical fitness, which is associated with a large academic load of primary school students, violation of the sleep-wake schedule, decrease of motor activity of children. The issue of health preservation is a subject of researches of many scientists, who consider various aspects of this problem: promoting a healthy lifestyle, physical education, health, culture, healthy lifestyle of primary school students, the preservation and strengthening of health of pupils in a family. A teacher is responsible for the implementation of this task: the main attention should be focused on the preparation of a new generation of teachers, the improvement of their general culture, and professional qualifications. Considering the above mentioned, the higher education is aimed at preparing a future physical education teacher for conscientious performance of health promotion and preventive work with primary pupils, who can not only teach and educate students, but also form their health culture and axiological attitude towards their health. Unfortunately, higher education not only fails to fulfill the task of preparing future teachers for health-educational activities, but also the problem of preserving the health of students is becoming more and more important. It is necessary to make primary school students maintain strict personal hygiene and improve these skills.

Keywords: physical education, future teachers, younger students, physical health, mental health.

Рецензент: д. мед. н., проф. О. П. Романчук

Подано до редакиії 04.04.2016

УДК: 796.011.1-057

Сузанна Олександрівна Ігнатенко, кандидат педагогічних наук, дочент кафедри теорії методики фізичного виховання, лікувальної фізкультури та спортивної медицини, Південноукраӥнський національний педагогічний університет імені К. Д. Уиинського, вул. Фонтанська дорога, 4, м. Одеса, Украӥна

\section{ФОРМУВАННЯ МОТИВАЦІї СТУДЕНТІВ ДО САМОСТІЙНИХ ЗАНЯТЬ ФІЗИЧНОЮ КУЛЬТУРОЮ}

У статті розглядається процес формування мотивації студентів до самостійних занять фізичною культурою, які є могутнім стимулом залученням молоді до здорового способу життя та формують культуру здоров'я особистості. Для розвитку мотивації до занять фізичними вправами $і$ дотримання здорового способу життя є спрямованість системи університетського виховання і освіти, направленої на активізацію мотиваиійних інтересів студентської молоді. Розкривається значимість самостійності оздоровчих занять атлетичною гімнастикою у підвищенні рівня соматичного здоров'я студентів. Запропоновано методику формування мотивації до фізкультурно-спортивної діяльності на прикладі занять атлетичною гімнастикою.

Ключові слова: студентська молодь, мотивація, самостійні заняття, атлетична гімнастика.

Постановка проблеми. Студенти - основний трудовий резерв держави, майбутні батьки, і їх здоров'я і благополуччя є запорукою здоров'я і благополуччя всієї нації. Студентство, особливо на початковому етапі навчання, $€$ найуразливішою частиною "Наука і освіma", №4, 2016 суспільства, тому що його спіткає низка труднощів, пов'язаних зі збільшенням навчального навантаження, низьким рівнем рухової активності, відносною свободою студентського життя, проблемами в соціальному і міжособистісному спілкуванні. У зв'язку з 
цим велике значення має вивчення мотивів, інтересів і потреб сучасної молоді, пов'язаних із фізичною культурою. Формування мотивації $\epsilon$ однією 3 основних умов забезпечення високої результативності будьякого освітнього процесу. Однак, на сучасному етапі недостатньо уваги приділяють питанням фізкультурно-оздоровчої діяльності у студентів, що обумовлено ставленням до масової фізичної культури в суспільстві, серйозними недоліками в сімейному і шкільному вихованні, відсутністю мотивації або іiі недооцінюванням на всіх етапах фізичного вдосконалення людини [4].

Мотивами можуть бути різні інтереси, прагнення, потяги, установки, ідеали тощо. Мотиви пояснюють прагнення людини щось зробити, чогось досягти. Насправді людину спонукає до діяльності не один, а кілька взаємозв'язаних мотивів. У мотивації до будьякої діяльності мотиви зазвичай вибудовуються в ряд. Це - структура мотивації, в якій завжди є домінуючі і другорядні мотиви. Мотиви будь-якої діяльності виникають і формуються, розвиваються і коректуються під впливом загального розвитку [6].

Життя сучасної студентської молоді супроводжується інформаційними та емоційними перевантаженнями, які дуже часто призводять до зриву адаптаційних процесів організму, за якими слідують різні відхилення у стані здоров'я, погіршення функціонального стану організму студента, що призводить до зниження його працездатності. Дані лікарського контролю свідчать про те, що на фоні зростання хронічних захворювань рівень фізичного здоров'я студентів знижується 3 кожним роком та збільшується чисельність студентів за станом здоров'я, віднесених до спеціальних медичних груп [8]. Така ситуація вимагає нових дієвих засобів і методів для вирішення проблеми зміцнення фізичного і духовного здоров'я молоді. Рухова активність є одним із визначальних чинників здоров'я людини. Неусвідомлене ставлення студентів до свого здоров'я, нерозуміння сприятливого впливу фізичної культури на його стан, невисока мотивація до занять фізичними вправами, нерозвиненість навичок самоконтролю - все це призводить до зниження рівня рухової активності, і як наслідок - до погіршення здоров'я. Тому, на наш погляд, одним із завдань фізичного виховання у ВНЗ має бути формування у студентів стійкої мотивації до самостійних занять фізичними вправами та ведення здорового способу життя у своєму повсякденному побуті.

Аналіз останніх досліджень і публікацій. Одним 3 основних завдань фізичного виховання $є$ формування потреби студента до занять фізичною культурою і спортом. Вивченню мотивації до занять фізичною культурою і спортом як головної умови формування повноцінної навчальної діяльності студента та значущої складової управління процесом виховання особистості присвятили свої роботи А. Пуні, Г. Горська, Т. Лапко, О. Дашкевич, В. Зобков. Аналіз психолого-педагогічної літератури та наукових праць свідчить, що питання мотиваційно-ціннісного ставлення до фізкультурної діяльності та рухової активності вивчали А. Ковальов, А. Пономаренко, Н. Дикань, О. Афанасенко, Я. Крушельницька та ін. Проблему самостійних занять фізичними вправами дослідили С. Васів, А. Козленко, К. Плотніков, В. Шерета, а формування мотивів та інтересів до фізичного самовдосконалення розглянуто у роботах М. Зубалія, С. Бодюкова, М. Солопчука, Г. Калачева. Разом з тим аналіз спеціальної літератури (А. Драчук, Т. Круцевич, і, Карпова) вказує на те, що сучасна організація фізичного виховання $є$ не досить ефективною для підвищення рівня фізичної підготовленості, здоров'я та зацікавленості більшості студентів до занять фізичними вправами. Це свідчить про нагальну потребу розробки нових науково обгрунтованих шляхів до формування та підвищення мотивації до самостійних занять фізичною культурою та спортом студентів вищих навчальних закладів.

Метою статті є дослідження формування та підвищення мотивації до самостійних занять фізичною культурою студентів вищих навчальних закладів.

Виклад основного матеріалу. Мотив - це спонукання людини до активності, пов'язане 3 намаганням задовольнити певні потреби. Внаслідок усвідомлення і переживання потреб у людини виникають певні спонукання до дій, внаслідок яких ці потреби задовольняються. Мотиви діяльності, за словами А. Леонтьєва, це багатогранне поняття, яке включає в себе потреби, установки, інтерес, звички, спонукання, бажання, схильності [10]. Термін «мотивація» науковці розглядають набагато ширше за поняття «мотив». Я. Крушельницька мотивацією називає систему мотивів, яка визначає конкретні форми діяльності або поведінки людини [9]. На думку А. Пономаренко, мотивація - це сукупність внутрішніх і зовнішніх рушійних сил, які спонукають людину до діяльності, задають межі і форми діяльності та додають цій діяльності спрямованість, орієнтовану на досягнення певних цілей. Н. Дикань вважає, що мотивація - це готовність людей докласти максимальних зусиль 3 метою досягнення організаційних цілей, що зумовлена здатністю цих зусиль задовольняти певну індивідуальну потребу [5]. На нашу думку, мотивація - процес формування й обгрунтування намірів щось зробити або не зробити. Вплив мотивації на поведінку людини залежить від безлічі факторів, які ми поділили на наступні групи: 1) потреби як основа активності; 2) причини, які обумовлюють вибір діяльності, залежно від спрямованості особистості; 3) суб'єктивні переживання, емоції як форми регуляції (саморегуляції) багато в чому індивідуальні і можуть змінюватися під впливом зворотного зв'язку з боку діяльності людини. У навчальній діяльності проявляються такі мотиви:

- пізнавальні, спрямовані на процес навчання (оволодіння знаннями і способами діяльності, потреби до інтелектуальної активності, рішення важко досяжних цілей тощо); 
- соціальні (мотиви обов'язку, відповідальності, самовизначення, самовдосконалення);

- вузькоособисті (мотиви благополуччя, престижу, уникнення неприємностей тощо).

Фізкультурна діяльність студентів має наступну класифікацію мотивів:

- мотиви, пов'язані із задоволенням процесом діяльності (динамічність, емоційність, новизна, різноманітність, спілкування та ін.);

- мотиви, пов'язані із задоволенням результатом занять (набуття нових знань, умінь і навичок, оволодіння різноманітними руховими діями, випробування себе, поліпшення результату та ін.);

- мотиви, пов'язані з баченням конкретних перспектив занять (фізична досконалість і гармонійний розвиток, виховання особистісних якостей, зміцнення здоров'я, підвищення спортивної кваліфікації та ін.) [9].

Для підвищення мотивації студентів до систематичних самостійних занять фізичною культурою необхідно дати повний обсяг інформації про засоби і методи фізичного виховання. Слід показати соціальну значимість фізичної культури, як для окремої особистості, так і для суспільства в цілому, що дозволить підвищити інтерес студентської молоді до занять фізичною культурою. Процес формування мотивації до занять спортом - це не одномоментний, а багатоступеневий процес: від перших елементарних гігієнічних знань і навичок (у дитячому віці) до глибоких психофізіологічних знань теорії і методики фізичного виховання й інтенсивних занять спортом [6].

Мотиваційно-ціннісні орієнтації особистості на активне позитивне ставлення до фізичної культури в усіх сферах життєдіяльності відображають сформовану потребу в ній, систему знань і переконань, які організовують, направляють на пізнавальну і практичну діяльність [2]. Мотивація є головним компонентом для успішного виконання будь-якої діяльності, у тому числі і фізкультурно-спортивної. Самостійні заняття фізичними вправами заповнюють дефіцит рухової активності студентів, сприяють більш ефективному відновленню організму і підвищенню фізичної й розумової працездатності. Студенти, які займаються самостійно фізичними вправами, повинні спиратися на науково-методичну допомогу всіх кафедр факультету фізичного виховання. Планування таких самостійних занять здійснюється ними за безпосередньої участі викладачів з фізичного виховання, тренерів та медиків. Залучення студентів до самостійних занять поза рамками програми предмету «Фізичне виховання» $є$ підвищенням їхнього освітнього рівня в питаннях оздоровчої фізичної культури. Потреба в русі забезпечить нормальний розвиток і життєдіяльність організму студента, сприятиме залученню його до систематичних занять фізичною культурою як в рамках навчального процесу, так і поза ним.

Протягом 2015 н. р. кафедрою ТМФВ, ЛФК та СМ ПНПУ імені К. Д. Ушинського був проведений педагогічний експеримент серед студентів 2 курсу факультету фізичного виховання, в якому взяло участь 133 студенти. Для збільшення рухової активності, підвищення фізичного розвитку студентів ми запропонували заняття атлетичною гімнастикою для самостійних занять фізичними вправами.

Атлетична гімнастика - система різнобічних силових вправ, спрямованих на розвиток сили, формування пропорційної фігури й зміцнення здоров'я. Атлетична гімнастика рятує від багатьох фізичних вад: сутулість, впалі груди, неправильна постава, слаборозвинені м'язи тощо. Атлетична гімнастика призначена для самих різних людей і ії слід розглядати як розвиваючий засіб фізичного виховання [3]. Вона заснована на використанні комплексів силових вправ із різними обтяженнями (штанга, гантелі, гирі, тренажери) та являє собою систему вправ, яка розвиває силу разом із витривалістю, спритністю й деякими іншими фізичними якостями, які сприяють зміцненню здоров'я. Заняття атлетичною гімнастикою дають помітний ефект тренувань уже протягом декількох місяців та дозовано впливають на недостатньо розвинуті м'язові групи. Силовими тренуваннями вирішують питання дозвілля молоді, відволікають від шкідливих звичок, прищеплюють самодисципліну, вона є засобом активного відпочинку й формування здорового способу життя [7].

У результаті позитивного впливу систематичних занять атлетизмом на центральну нервову систему змінюється і тип особистості студента, його психічний статус. Психологи вважають, що студенти, які займаються атлетичною гімнастикою, стають більш товариськими, контактними, доброзичливими, мають більш високу самооцінку і впевненість у своїх силах і можливостях. Науковцями доведено багатогранний i сильний позитивний вплив на організм людини занять атлетичною гімнастикою, зокрема на серцевосудинну систему та органи дихання. Регулярні тренування з обтяженнями позволяють людині збільшувати м'язову силу; підвищувати м'язову витривалість; зміцнювати суглоби, кістки і зв'язки, збільшувати число капілярів у м'язах (а значить насичення киснем організму, що важливо при різних захворюваннях); збільшувати гнучкість; покращувати здоров'я і фізичну підготовленість; підвищувати рівень обміну речовин, контролювати власну вагу і знижувати відсоток жиру в організмі $[3,7,8]$. Під час організації занять 3 атлетичної гімнастики потрібно враховувати багато факторів: біологічні особливості юнаків, загальний рівень фізичної підготовки [3].

Педагогічний експеримент проходив в три етапи. На першому етапі ми виявили ставлення студентів до занять фізичною культурою і цінностей здоров'я. За допомогою анкетування, опитування, бесіди ми встановили, що студенти досить високо усвідомлюють соціальну цінність здоров'я в житті суспільства i структурі життєдіяльності. Фізична активність за результатами опитування студентів мала наступні ре- 
зультати: $31 \%$ юнаків віднесли себе до спортсменів та фізкультурників, 37\% опитаних студентів вважають достатнім власний руховий режим для повсякденної діяльності та збереження здоров'я. Однак, лише 23\% студентів займаються самостійно (в позаурочний час) фізичними вправами і витрачають 6-7 годин на тиждень, що відповідає вимогам раціонального рухового режиму. Всього лише $17 \%$ опитаних респондентів вважають необхідними заняття фізичною культурою для успіху в майбутній професійній діяльності. Головними перешкодами для активних самостійних занять фізичними вправами і спортом опитані студенти назвали: 1) недостатню інформованість важливості рухової активності у зміцненні здоров'я; 2) відсутність практичних умінь і навичок в організації самостійних занять 3 фізичної культури; 3) невміння планувати $і$ використовувати фізичні вправи з урахуванням особливостей статури і фізичної підготовленості; 4) відсутність навичок самоконтролю. У ході дослідження ми виявили основні мотиви для занять фізичною культурою: поліпшити фігуру, поставу; зміцнити здоров'я; бажання рухатися; розвинути фізичні якості; підняти самооцінку та впевненість у власних силах; емоційне розвантаження, гарний настрій.

На другому етапі нашого дослідження, за підсумками анкетування, опитування, бесід, студентам, які виявили бажання самостійно займатися атлетичною гімнастикою, була запропонована програма атлетичних тренувань із комплексами вправ на різні групи м'язів 3 урахуванням рівня функціонального стану організму студентів і мотивів до самостійних занять атлетизмом, розроблена викладачами кафедри ТМФВ, ЛФК та СМ. На заняттях використовувався інформаційний підхід, який реалізувався в теоретичній частині практичних занять 3 фізичної культури у формі індивідуальних і групових бесід, підбору для студентів спеціальної літератури. Під час практичних занять особлива увага приділялась профілактиці травм у процесі силової підготовки, наголошувалось на необхідності розминки перед силовим тренуванням, контролювались величини обтяжень та загальний обсяг силових навантажень та їх поступове збільшення, особливо на початковому етапі занять силовими вправами; контролювалось засвоєння техніки виконання вправи. Таким чином, студентам було надано необхідний обсяг знань і методичних умінь для самостійних занять атлетичною гімнастикою.

Протягом всього періоду самостійних занять атлетизмом студенти заповнювали щоденник самоспостереження, де фіксувалися результати самоконтролю. Спираючись на записи в щоденнику самоспостереження, спільно з викладачем періодично аналізувалася ефективність навантаження, кількість підходів тощо. До кінця експерименту студент вже сам вносив корективи у свою програму тренування.

На третьому етапі нашого дослідження проводилося тестування за експрес-методикою Г. Л. Апанасенко [1] для визначення рівня соматичного здоров'я студентів-юнаків, які самостійно займалися атлетизмом на початку експерименту та після його закінчення (табл. 1).

Разом із дослідженням поліпшення показників рівня соматичного здоров'я студентів нами вивчався психоемоційний стан після самостійних занять атлетичною гімнастикою, який оцінювалася за допомогою педагогічних спостережень. Результати дослідження показали, що після занять у тренажерному залі та виконання силових вправ 3 навантаженнями емоційний стан у $78 \%$ студентів поліпшувався.

Таблиця 1.

Експрес-оцінка рівня соматичного здоров'я студентів (за. Г. Л. Апанасенком)

\begin{tabular}{|l|c|c|}
\hline \multirow{2}{*}{ Рівень } & \multicolumn{2}{|c|}{ Етапи експерименту } \\
\cline { 2 - 3 } & До & Після \\
\hline Низький, \% & 14,2 & 11,7 \\
\hline Нижче середнього, \% & 52,7 & 46,1 \\
\hline Середній, \% & 24,5 & 30,1 \\
\hline Вище середнього, \% & 7,1 & 9,8 \\
\hline Високий, \% & 1,5 & 2,3 \\
\hline
\end{tabular}

Студенти відзначали розрядку і нейтралізацію негативних емоцій, які виникали під час навчання. У $14 \%$ емоційний стан протягом заняття змінювався незначно. Під час педагогічних спостережень у 19\% молодих людей відзначалися скарги на больові відчуття у м'язах під час силового тренування з навантаженням. Хотілося б відзначити, що $89 \%$ студентів досягли бажаного результату. 3 цього числа 64\% покращили статуру; 70\% підвищили функціональний стан організму; 90\% підвищили рухову активність; $89 \%$ поліпшили показники сили; $10 \%$ студентів не отримали емоційного задоволення і не досягли бажаних результатів. Отримані результати вони пояснюють тим, що цей вид рухової активності їм не підходить.

У ході нашого дослідження студенти покращили рівень здоров'я, отримали достатній обсяг інформації про важливість рухової активності у його зміцненні; придбали практичні вміння та навички в організації самостійних занять фізичними вправами; навчилися використовувати фізичні вправи з урахуванням особливостей статури і фізичної підготовленості; набули 
навичок самоконтролю. Майже всі студенти продовжують самостійно займатися атлетичною гімнастикою.

Висновки i перспективи подальших досліджень. Для підвищення мотивації студентів до систематичних самостійних занять фізичними вправами та спортом необхідно дати повний обсяг інформації про засоби і методи фізичного виховання. Необхідно показати соціальну значимість фізичної культури як для окремої особистості, так і для суспільства в цілому, що дозволить підвищити інтерес студентської

\section{ЛІТЕРАТУРА}

1.Апанасенко Г. Л. Проблемы управления здоровьем человека // наука в олимп.спорте. Спец. Выпуск 1/ Г. Л. Апанасенко. - С. 56-60.

2. Афанасенко Е. А. Формирование мотивационно-ценностного отношения к физической культуре у студентов специальной медицинской группы: автореферат. дис. канд. пед. наук. / Е. А. Афанасенко. - Москва. - 2006. -25 с

3.Бодюков Е. В. Научно-методические основы атлетической гимнастики оздоровительной направленности. Монография / Е. В. Бодюков. - Барнаул: АмГТУ, 2006. - 182 с.

4.Губенко О. В. Психологічні особливості популяризації здорового способу життя у вищих навчальних закладах // Практична психологія і соціальні роботи. -2009 . - №11. - С. 35.

\section{REFERENCES}

1. Apanasenko, G. L. Problemy upravleniya zdoroviem cheloveka [Problems of human health protection]. Nauka $v$ olympiyskom sporte - Science in Olympic sports, 1, 56-60 [in Russian].

2. Afanasenko, E. A. (2006). Formirovaniie motivatsionno-tsennostnogo otnosheniya $\mathrm{k}$ fizicheskoi kulture $\mathrm{u}$ studentov spetsyalnoi meditsinskoi gruppy [Formation of motivational and axiological attitude towards physical training in students of special medical groups]. Extended abstract of Candidate's thesis. Moscow [in Russian].

3. Bodyukov, E.V. (2006). Nauchno-metodicheskie osnovy atleticheskoi gimnastiki ozdorovitelnoi napravlennosti [Scientifically-methodical bases of athletic gymnastics of recreational focus]. Barnaul: AmGhTU [in Russian].

4. Gubenko, O. V. (2009). Psykhologhichni osoblyvosti populiaryzatsii zdorovoho sposobu zhyttia u vyshhykh navchalnykh zakladakh [Psychological peculiarities of healthy lifestyle popularization in higher education]. Praktychna psykholohiia $i$ sotsialni roboty -

молоді до занять фізичною культурою. Успішна реалізація мотивів викликає у студентів бажання й інтерес до самостійних занять фізичними вправами, сприяє формуванню позитивної думки про власну особистість, впевненості в собі, допомагає долати або значно послаблювати стрес i напруження повсякденного життя, розвиває самодисципліну. В подальшому планується дослідження впливу запропонованих методів підвищення мотивації студентів до самостійних занять фізичними вправами та спортом.

5.Дикань Н. В. Менеджмент: нав. посібник / Н. В. Дикань, I. І. Борисенко. - К.: Знання, 2008. - 389 с.

6. Ильин Е. П. Мотивация и мотивы / Е. П. Ильин. - СПБ.: Питер, 2006. - 508 с.

7.Калачев Г. А. Физиология мышечной деятельности и спорта.: Учеб. Пособие / Г. А. Калачев. - Барнаул, 2004. - 226 с.

8. Круцевич Т. Ю. Методы исследования индивидуального здоровья детей и подростков в процессе физического воспитания / Т. Ю. Круцевич. - К.: Олімпійська література, 1999. - 168 с.

9.Крушельницька Я. В. Фізіологія і психологія праці.: Підручник / Я.В. Крушельницька. - Київ, 2003. - 367 c

10. Леонтьев А. Н. Потребности, мотивы, эмоции / А. Н. Леонтьев. - М., 1971. - 196 с.

Practical psychology and social work, 11, 35 [in Ukrainian].

5. Dikan, N. V., Borisenko, I. I. (2008). Menedzhment [Management]. Kyiv: Znannia [in Ukrainian].

6. Ilin, E. P. (2006). Motivatsiia i motivy [Motivation and motives]. Saint Petersburg: Piter [in Russian].

7. Kalachev, G. A. (2004). Fiziologiya myshechnoy deyatelnosti i sporta [Physiology of muscle activity and sport]. Barnaul [in Russian].

8. Krutsevich, T. Yu. (1999). Metody issledovaniya individualnogo zdorovia detey $i$ podrostkov $v$ protsesse fizicheskogo vospitaniya [Research methods of individual health of children and adolescents in the process of physical training]. Kyiv: Olimpiyska literatura [in Russian].

9. Krushelnitska, Ya. V. (2003). Fiziologhiia $i$ psykhologhiia pratsi [Physiology and psychology of work]. Kyiv [in Ukrainian].

10. Leontiev, A. N. (1971). Potrebnosti, motivy, emotsii [Needs, motives, emotions]. Moscow [in Russian].

Сузанна Александровна Игнатенко, кандидат педагогических наук, доиент кафедры теории методики физического воспитания, лечебной физкультуры и спортивной медичины, Южноукраинский нацииональный педагогический университет имени К. Д. Ушинского, ул. Фонтанская дорога, 4, г. Одеса, Украина

ФОРМИРОВАНИЕ МОТИВАЦИИ СТУДЕНТОВ К САМОСТОЯТЕЛЬНЫМ ЗАНЯТИЯМ ФИЗИЧЕСКОЙ КУЛЬТУРОЙ

В статье рассматривается процесс формирования мотивации студентов к самостоятельным занятиям физической культурой, которые являются мощным стимулом для привлечения молодых людей к здоровому образу жизни, 
формируют культуру здоровья личности. Для формирования мотивации к занятиям физическими упражнениями и соблюдению здорового образа жизни существует направленность системы вузовского воспитания и образования, ориентированная на активизацию мотивационных интересов студенческой молодежи. Мотивация - система мотивов, которая определяет конкретные формы деятельности или поведения. Она является ключевым компонентом успешной деятельности, в том числе физической подготовки. Самостоятельные занятия позволяют заполнить нишу двигательной активности студента, а также помочь восстановить более эффективно уровень физической и умственной трудоспособности. Раскрывается значимость самостоятельных оздоровительных занятий атлетической гимнастикой в повышении соматического здоровья студентов. Самостоятельная работа студентов является одной из основных форм занятий, поскольку формирует самостоятельность как качество личности и готовит к постоянному самосовершенствованию. Правильная организация самостоятельных занятий физическими упражнениями студентов способствует повышению их двигательной активности, рациональному проведению досуга, положительно влияет на здоровье, физическое развитие, двигательную подготовленность молодежи, и, как следствие, воспитывает потребность в систематических занятиях физической культурой. В различных формах учебного процесса самостоятельность проявляется по-разному: от простого воспроизведения, выполнения задания до самостоятельной творческой работы. Предложена методика формирования мотивации к физкультурно-спортивной деятельности на примере атлетической гимнастики - это система силовых упражнений, направленных на развитие силы, формирование пропорциональной фигуры и укрепление здоровья. Атлетическая гимнастика также избавляет от многих физических недостатков: сутулость, впалая грудь, неправильная осанка, слаборазвитые мышцы и т.д. Она предназначена для самых разных людей и ее следует рассматривать как развивающие направление физического воспитания в качестве самостоятельных занятий для студентов высших учебных заведений.

Ключевые слова: студенческая молодежь, мотивация, самостоятельные занятия, атлетическая гимнастика.

\section{Suzanna Ihnatenko, \\ PhD (Candidate of Pedagogical Sciences), associate professor, Department of Theory and Methods of Physical Education, Remedial Gymnastics and Sports Medicine, South Ukrainian National Pedagogical University named after K. D. Ushynsky, 4, Fontanska Doroha Str., Odesa, Ukraine}

FORMING STUDENTS' MOTIVATION TO SELF-GUIDED PHYSICAL TRAINING

The article deals with the process of forming motivation in students to self-guided physical training, which is a powerful incentive of bringing young people to a healthy lifestyle which forms the health culture. To generate physical training motivation and keep a healthy lifestyle there is a direction in the system of higher education aimed at enhancing motivational interests of students. Motivation is considered as a system of motives, which determines the specific forms of activity or behavior. It is a key component of the successful activities, including physical training. Self-guided physical training allows supplying the lack of students' motor activities, and restoring a level of physical and mental capacity. The selfguided recreational activities by means of artistic gymnastics are extremely important in the process of improving the physical health of students. It is one of the basic forms of training, because it forms independence as the personality trait and prepares an individual for constant self-improvement. Proper organization of self-guided physical training improves students' motor activity, has a positive effect on their health and physical development and fitness, and as a result, instills the need for systematic physical training. In various forms of the educational process self-guided training is manifested in different ways: from a simple reproduction of the assignment to independent creative work. The technique of forming sports motivation in students through the example of artistic gymnastics has been presented in the article. It is considered as a system of power exercises aimed at developing strength, forming a good shape and promoting health. It helps to recover from many physical disorders: stoop, hollow breast, bad posture, underdeveloped muscles, etc. Artistic gymnastics is suitable for many people and it should be regarded as a developing direction of physical education as a self-guided physical work for students of higher educational institutions.

Keywords: university students, motivation, self-guided training, artistic gymnastics.

Подано до редакиіï 04.04.2016

Рецензент: д. мед. н., проф. О. П. Романчук 